\section{Effects of peripherally induced anosmia on mating behavior of male mice}

\author{
FRANK A. ROWE and WILLIAM E. SMITH \\ Illinois Institute of Technology, Chicago, IIl. 60616
}

Anosmia produced by an application of a $5 \%$ solution of zinc sulfate to the olfactory mucosa failed to abolish mating behavior in male mice. This finding is consistent with the idea of multisensory control of mating behavior in male rodents and indicates that deficits observed after bulbectomy are a consequence of factors other than anosmia.

Past attempts to assess the importance of olfaction for the occurrence of mating behavior in male rodents have depended upon bilateral olfactory bulb ablation as the only reliable method for inducing anosmia. The results of experiments using this technique indicate the existence of species differences with respect to the importance of olfaction for masculine mating behavior. In male rats, bulbectomy produces a deficit that varies in severity as a function of the amount of preoperative sexual experience and as a function of characteristics of the postoperative tests of mating behavior (Beach, 1942; Heimer \& Larsson, 1967; Bermant \& Taylor, 1969). On the other hand, in sexually experienced male hamsters and mice, bulbectomy totally abolishes mating behavior (Murphy \& Schneider, 1970; Rowe \& Edwards, 1972). However, it is impossible to demonstrate unequivocally a relationship between olfaction and mating behavior on the basis of evidence gained from experiments in which anosmia was produced by destruction of central nervous system tissue. This is due to the fact that, in addition to anosmia, bulbectomy could be producing other effects that contribute to postoperative deficits in mating behavior.

It has recently been demonstrated that anosmia can be produced in male rats by applying a $5 \%$ solution of zinc sulfate to the olfactory mucosa (Alberts \& Galef, 1971). This technique has the advantage of producing anosmia without damaging central nervous system tissue, and in most cases, the anosmia is completely reversible. The present study investigated the effects of zinc-sulfate-induced anosmia on mating behavior in sexually experienced male mice.

$$
\text { METHOD }
$$

The Ss for this experiment were male Swiss-Webster albino mice that had demonstrated their copulatory ability by achieving an ejaculation on at least two out of five tests of mating behavior. These, and all subsequent tests of mating behavior, were conducted in the males' home cages and consisted of pairing each male with a receptive female for $90 \mathrm{~min}$. During this time, the following aspects of the males' behavior were recorded: mount frequency, intromission frequency, latency to first mount (ML), latency to first intromission (IL), and latency to first ejaculation (EL). Stimulus fermales for all tests were ovariectomined, and estrus was; induced by injections of estradiol benzoate and progesterone.

Males inere assigned randomly $t:$ ? one of ituree grouigs. In one group $(\mathrm{N}=8)$, males had a $5 \%$ solution of zine sulfate applied to their olfactory receptors, males in the second group applied to their olfactory receptors, and males in the third group $(\mathrm{N}=5)$ served as untreated controls. The technique of administering the zinc sulfate and saline treatments has been described elsewhere (Alberts \& Galef, 1971), and all treatments were performed while Ss were anesthetized with ether.

Olfactory ability was assessed by giving each $\mathrm{S}$ four olfactory preference tests: one $24 \mathrm{~h}$ before treatments were administered, and one $24 \mathrm{~h}, 72 \mathrm{~h}$, and 10 days after treatments were administered. Preference tests were $5 \mathrm{~min}$ long and consisted of measuring the amount of time that the Ss spent investigating each of two identical tin $(N=5)$ had physiological saline cans ( $8 \mathrm{~cm}$ long and $5 \mathrm{~cm}$ in diam). Inside of one can was a stainless steel cup containing a small amount of peanut butter (baited can), while the other can contained an identical, but empty, cup (neutral can). The cans were inserted into holes in the corners of one end of a cage identical to the Ss' home cages. The inside of each can was divided into two 4-cm-long chambers by a piece of aluminum screen. The screen prevented Ss from gaining access to the cups but allowed air to flow through the cans. Prior to the first olfactory preference test, the position preference of each male was determined. The nonpreferred can served as the baited can in the first preference test, and in the three subsequent tests, the baited can was determined by tossing a coin. All olfactory preference tests were conducted while the $\mathrm{Ss}$ were $24 \mathrm{~h}$ food deprived. Males had ad lib access to water ihroughout the experiment, and, oxcept for the $24 \mathrm{~h}$ immediately preceding preference tests, food was frumy available. In addition to lab sirow , Ss received a small amount of non? butter each day.

Warth male received a test of mating behavior $48 \mathrm{~h}$ and 11 days after the treatments were administered. In addition, each $S$ was weighed immediately before the treatments were administered, immediately after the first posttreatment test of mating behavior, and $24 \mathrm{~h}$ after the second posttreatment preference test.

\section{RESULTS}

All of the Ss in each group mounted resoptive females during the test of mating behavior that occurred $48 \mathrm{~h}$ after the treatments were administered. Analyses of variance of all of the latency scores failed to reveal any differences among the zinc-sulfate-treated males and the untreated saline-treated males (ML $F=2.31, \quad \mathrm{df}=1 / 16, \quad \mathrm{p}>.05 ; \quad$ IL $F=2.30, \quad d f=1 / 11, \quad p>.05 ; \quad E L$ $\mathrm{F}<1$, df $=1 / 11$ ). Likewise, chi-square analyses indicated that the groups did not differ with respect to the number

Table 1 Mating Behavior of Male Mice

\begin{tabular}{|c|c|c|c|c|}
\hline \multirow[b]{2}{*}{ Group: } & \multicolumn{2}{|c|}{$48 \mathrm{~h}$ Posttreatment } & \multicolumn{2}{|c|}{11 Days Posttreatment } \\
\hline & $\begin{array}{c}\text { Zinc } \\
\text { Sulphate }\end{array}$ & $\begin{array}{c}\text { Saline + } \\
\text { Untreated }\end{array}$ & $\begin{array}{c}\text { Zinc } \\
\text { Sulphate }\end{array}$ & $\begin{array}{c}\text { Saline + } \\
\text { Untreated }\end{array}$ \\
\hline $\begin{array}{l}\text { Percent } \\
\text { Mounting }\end{array}$ & 100 & 100 & 100 & 100 \\
\hline $\begin{array}{l}\text { Percent } \\
\text { Ejaculating }\end{array}$ & 50 & 60 & 50 & 60 \\
\hline $\begin{array}{l}\text { Mean ML (Min) } \\
\quad( \pm 1 \text { SEM })\end{array}$ & $24.7 \pm 10.3$ & $8.9 \pm 4.3$ & $12.1 \pm 6.9$ & $7.5 \pm 2.3$ \\
\hline $\begin{array}{l}\text { Mean EL (Min)* } \\
\quad( \pm 1 \text { SEM })\end{array}$ & $35.2 \pm 7.8$ & $43.4 \pm 11.0$ & $31.1 \pm 5.6$ & $53.3 \pm 6.5$ \\
\hline
\end{tabular}

*Based on the data of only those $S$ s that achieved ejaculation 
Table 2

Mean ( \pm 1 SEM) OLfactory Preference Test Scores*

\begin{tabular}{|c|c|c|c|c|c|}
\hline Group & $\mathbf{N}$ & $\begin{array}{c}24 \mathrm{H} \\
\text { Before } \\
\text { Treatment }\end{array}$ & $\begin{array}{c}24 \mathrm{H} \\
\text { After } \\
\text { Treatment }\end{array}$ & $\begin{array}{c}72 \mathrm{H} \\
\text { After } \\
\text { Treatment }\end{array}$ & $\begin{array}{c}10 \text { Days } \\
\text { After } \\
\text { Treatment }\end{array}$ \\
\hline $\begin{array}{l}\text { Zinc Sulphate } \\
\text { Saline + Untreated }\end{array}$ & $\begin{array}{r}8 \\
10\end{array}$ & $\begin{array}{l}2.41 \pm 0.19 \\
3.15 \pm 0.50\end{array}$ & $\begin{array}{l}0.99 \pm 0.04 \\
3.02 \pm 0.61\end{array}$ & $\begin{array}{l}1.06 \pm 0.07 \\
2.42 \pm 0.27\end{array}$ & $\begin{array}{l}1.95 \pm 0.23 \\
3.40 \pm 0.43\end{array}$ \\
\hline
\end{tabular}

*Tabled values represent the amount of time (seconds) spent investigating the baited can relative to the amount of time spent investigating the neutral can. For each $S$ this value was obtained by dividing the time in the baited can by the time in the neutral can.

of males achieving either intromissions $\left(x_{1}^{2}=3.55, p>.05\right)$ or ejaculations $\left(x_{1}^{2}=.18, p>.05\right)$. Table 1 summarizes the data on mating behavior.

The preference tests data indicate that the Ss treated with zinc sulfate were, in fact, anosmic during the first posttreatment test of mating behavior (Table 2). Twenty-four hours before and after the test of mating behavior, the zinc-sulfate-treated males spent approximately the same amount of time investigating each can. In contrast to the zinc sulfate males, untreated and saline-treated males spent more than twice as much time investigating the baited can as they spent investigating the neutral can, both before and after the test of mating behavior.

Ten days after the treatments were administered, all Ss were given a final preference test, which was followed $24 \mathrm{~h}$ later by a final test of mating behavior. Once again, there were no differences among the groups on any of the measures of mating behavior. However, there was evidence of recovery of olfaction in the zinc-sulfate-treated males. This was indicated by the fact that $62 \%$ of these Ss now spent at least twice as much time investigating the baited can as they spent investigating the neutral can. The untreated and saline-treated males continued to demonstrate a definite preference for the baited can.

The zinc-sulfate-treated $S$ s and the untreated and saline-treated Ss did not differ in body weight either before or after treatments were administered $(F<1, d f=1 / 16)$; however, all $S s$ weighed significantly less after treatment than before treatment $(\mathrm{F}=34.64, \mathrm{df}=2 / 32, \mathrm{p}<.05)$.

\section{DISCUSSION}

The present data strongly suggest that olfactory stimuli are not necessary for the occurrence of the complete pattern of mating behavior Only with respect to $\mathrm{ML}$ did the zinc-sulfate-treated Ss appear deficient relative to untreated and saline-treated Ss. Although not statistically significant, the mean $\mathrm{ML}$ for the zinc-sulfate-treated Ss was almost three times that for untreated and saline-treated $S s$ in the first posttreatment test of mating behavior (Table 1). However, inspection of the that the mean ML for this group was elevated due to the fact that two Ss exhibited exceptionally long latencies to the first mount $(70.5 \mathrm{~min}$ and $66.2 \mathrm{~min}$ ). When these two Ss' data are excluded, the mean ML for the zinc sulfate group is $10.1 \mathrm{~min}$, a value more in accord with that obtained by the untreated and saline-treated Ss. There was no obvious reason for the elevated mount latencies demonstrated by these two Ss.

In the present experiment, anosmia was operationally defined as Ss spending equal amounts of time investigating each can in the preference test. Zinc sulfate obviously produced anosmia according to this criterion. However, the failure of zinc-sulfate-treated $S$ s to demonstrate a preference for the baited can 24 and $48 \mathrm{~h}$ after treatment could conceivably be the consequence of a chemical-induced aversion to peanut butter or the fact that they were physically debilitated by the zinc sulfate. The former possibility appears unlikely in view of the fact that all zinc-sulfate-treated Ss continued to eat their daily ration of peanut butter. The fact that zinc sulfate Ss never differed in body weight from untreated and saline-treated $\mathrm{Ss}$ mitigates against the possibility that zinc sulfate Ss were sick. The significant reduction in body weight observed in all Ss following treatment was probably a consequence of the fact that all measures of body weight in sexually experienced male mice. data for each zinc sulfate $S$ indicated were made within a $96 \mathrm{~h}$ period, and for $48 \mathrm{~h}$ of this period, Ss were food deprived.

The results of this experiment are consistent with the widely held hypothesis that sexual behavior in male mammals is under multisensory control. Furthermore, the present data indicate that bulbectomy-induced deficits in mating behavior (Murphy \& Schneider, 1970; Rowe \& Edwards, 1972) and in other social behaviors, such as maternal behavior (Gandelman et al, 1971) and aggressive behavior (Rowe \& Edwards, 1971), nted not be the consequence of anosmia per se. In fact, the manner in which olfactory bulb ablation produces a deficit in each of the above behaviors could conceivably be different for each of the behaviors. Further research is needed to delineate the extent to which the behavioral consequences of olfactory bulb ablation can be attributed to anosmia, as opposed to other consequences of bulbectomy, such as altered levels of neurotransmittors in other areas of the brain (Pohorecky et al, 1969).

\section{REFERENCES}

ALBERTS, J. R \& GALEF, B G Acute anosmia in the rat: A behavioral test of a peripherally-induced olfactory deficit. Physiology \& Behavior, 1971, 6, 619-621.

$\mathrm{BEACH}$, F. A Analysis of the stimuli adequate to elicit mating behavior in the sexually inexperienced male rat. Journal of Comparative Psychology, 1942, 33, 163-207.

BERMANT G. \& TAYLOR $L$. Interactive effects of experience and olfactory bulb lesions in male rat copulation. Physiology \& Behavior, 1969,4,13-17.

GANDELMAN, R., ZARROW, $M$. X., DENENBERG, V. H., \& MYERS、 $M$. Olfactory bulb removal eliminates matemal behavior in the mouse. Science, $1971,171,210-211$

HEIMER, L. \& LARSSON, $K$. Mating behavior of male rats after olfactory bulb lesions. Physiology \& Behavior, 1967, 2, 207-209.

MURPHY, M. R., \& SCHNEIDER, G. E. Olfactory bulb removal eliminates mating behavior in male hamsters. Science, 1970. 167, 302-303.

POHORECKY, L. A., ZIGMOND, M. J./ HEIMER, L.. \& WURTMAN, R. J. Olfactory bulb removal: Effects on brain norepinephrine Proceedings of the National Academy of Sciences, 1969, 62, 1052-1055.

ROWE, F. A., \& EDWARDS, D. A. Olfactory bulb removal: Influences on the aggressive behaviors of male mice. Physiology \& Behavior, 1971, 7, 889-892 ROWE, F. A., \& EDWARDS, D. A Olfactory bulb removal: Influences on the mating behavior of male mice. Physiology \& Behavior, 1972, in press 